\title{
ASSESSMENT OF BIOPLASTIC PRODUCING POTENTIAL OF BACILLUS SUBTILIS USING SOME AGRICULTURAL RESIDUES AS CARBON SOURCE
}

\author{
Abdullahi B. Sallau ${ }^{\text {a, } * \text {, Bashir Salim }}{ }^{\text {a }}$, Aliyu Salihu ${ }^{\text {a }}$ \\ ${ }^{a}$ Faculty of Life Science, Ahmadu Bello University Zaria, Kaduna state Nigeria - (sallauabdullahi@gmail, \\ salihualiyu@yahoo.com and salimbashir@yahoo.com)
}

Received: Feb. 2018 / Accepted: Jun., 2018 / Published: Jun., 2018

https://doi.org/10.25271/2018.6.2.427

\begin{abstract}
:
This study was carried out to assess the bioplastic producing potential of Bacillus subtilis using a variety of pretreated agricultural residues. Four agricultural residues (rice husks, molasses, bagasse, and corn cobs) were subjected to acid, alkaline and oxidative pretreatments using standard procedures. Polyhydroxybutyrate (PHB) produced was extracted using chloroform precipitation and quantified spectrophotometrically. The PHB production $(\mathrm{g} / \mathrm{L})$ for acid, alkali and hydrogen peroxide pretreatments where $(n=3)$ were: $1.52 \pm 0.02,1.82 \pm 0.01$, and $1.70 \pm 0.01$ for rice husk; $1.82 \pm 0.01,1.52 \pm 0.02$, and $1.69 \pm 0.01$ for molasses; $0.87 \pm 0.06,1.10 \pm 0.10$, and $0.96 \pm 0.07$ for sugarcane bagasses and $0.5 \pm 0.00,0.77 \pm 0.06$, and $0.60 \pm 0.10$ for corn cob, respectively. The maximum bioplastic yield of $63.94 \pm 2.59 \%$ was obtained in alkali pretreated corn cobs, while the lowest yield of $50.33 \pm 0.76 \%$ was found in acid pretreated rice husk. Thus, the findings in this study revealed that agricultural residues could be explored for PHB production in the presence of potential microbial strains due to their abundance, high carbon content, limited inhibitory effect and cost effectiveness.
\end{abstract}

KEYWORDS: Bioplastics, Bacillus subtilis, Polyhydroxybutyrate, Agricultural residues, Pretreatment.

\section{INTRODUCTION}

Conventional polymers like plastics, which are manufactured from petrochemical materials have become indispensable products for human utilization. They are non-biodegradable and pose serious threat to the environment. Environmental pollution which has contributed to the effect of ozone layer depletion and greenhouse gas emission has driven research towards developing substitute for petrochemical products (Tripathi et al., 2009). Biopolymers like bioplastics represent a possible alternative to the traditional, non-biodegradable petrochemical derived polymers with comparable characteristics in terms of molecular weight, brittleness, stiffness and glass transition temperature (Barham, 1990; Jiun-Yee et al., 2010). Other additional advantages they possess over synthetic polymers include biodegradability, biocompatibility, environmental friendliness and can be produced from renewable sources (Saharan and Sharma, 2012) . Bioplastics (Polyhydroxyalkanoates) production have been reported to be achieved by different microorganisms via accumulation of polyhydroxybutyrate (PHB) as intracellular granules under stressed conditions of excess carbon and limited supply of other nutrients like oxygen, nitrogen and phosphate (Rodriguez-Contreras et al., 2013). Prokaryotic microorganisms, such as Escherichia coli (Insomphun et al., 2016), Bacillus megantum (Lopez et al., 2012), B. thuringiensis (Singh et al., 2009) and Pseudomonas putida (Wang et al., 2009) have been known to produce polyhydroxyalkanoate (PHA) and utilize it as carbon and energy source to enhance their survival under environmental stress conditions (Castro-Sowinski et al., 2010; Insomphun et al., 2016). Thus, renewable carbon sources associated with biomass, agro-residues, municipal or industrial wastes have shown considerable potential in sustaining PHA production (Braunegg et al., 1998; Sudesh and Iwata, 2008).
Due to its mechanical properties, PHB (a type of polyhydroxyalkanoate) has wide applications in the field of medicine and pharmaceuticals mainly in development of surgical biomaterials and drug delivery (Williams and Martin, 2002). In addition, bioplastics have found use as sutures, inplants, materials required for tissue engineering and microencapsulation among others (Luengo et al., 2003). The major challenge affecting the wider utilization of PHA is the high production cost when compared with the synthetic polymers (Byrom, 1987; Choi and Lee, 1997). Consequently, substantial efforts have been made in the use of genetically modified organisms (GMOs), cheap and available substrates with high carbon contents, improved techniques and methods of production (Lopez et al., 2012). It is in the light of the aforementioned this study was designed to explore the potentials of different agricultural residues for PHA production by Bacillus subtilis. This may contribute in reducing the overall production cost of PHA which often restricts its wider industrial applications; since more than $40 \%$ of the total operating expenses of PHA production are related to the raw materials (Hassan et al., 1996).

\section{MATERIALS AND METHODS}

\subsection{Sample Collection:}

The agricultural residues namely: sugarcane bagasse, rice husks and corn cobs were obtained from Numan Modern Market as refuse; while molasses was obtained from Savanna Sugar Company, Numan, Nigeria. Three of the samples (with the exception of molasses) were washed several times with tap water to remove any dirt and all the four samples were then oven-dried at $105^{\circ} \mathrm{C}$ for 3 hours. The samples were also transferred to a desiccator, sealed and allowed to cool at room temperature. The dried samples were ground to powder and sieved to $1 \mathrm{~mm}$ particle size and kept till further use.

\footnotetext{
* Corresponding author

This is an open access under a CC BY-NC-SA 4.0 license (https://creativecommons.org/licenses/by-nc-sa/4.0/)
} 


\subsection{Chemical Pretreatment of Samples:}

Acid, alkali and oxidative pretreatment of the samples were carried out at solid loading of $10 \%(\mathrm{w} / \mathrm{v})$ for solid carbon sources and $10 \%(\mathrm{v} / \mathrm{v})$ for molasses using $0.5 \mathrm{M} \mathrm{H} 2 \mathrm{SO} 4,0.5$ $\mathrm{M} \mathrm{NaOH}$ and $0.5 \mathrm{M} \mathrm{H} 2 \mathrm{O} 2$, respectively. The samples were autoclaved at $121^{\circ} \mathrm{C}$ for 20 minutes at 15 psi pressure as described by Singh and Bishnoi (2013) with slight modification. The samples were then repeatedly washed with water to remove the solvents used for pretreatment and then dried in an oven at $60^{\circ} \mathrm{C}$ to a constant weight. In case of molasses, it was filtered, dissolved in distilled water and then allowed to settle. The resulting mixture was decanted and the residue was used as carbon source for inoculation.

\subsection{Preparation of Media for Bacterial Growth:}

Nutrient media containing sucrose (1\%), magnesium sulphate $(0.02 \%)$, sodium chloride $(0.01 \%)$, dipotassium hydrogen phosphate $(0.05 \%)$, and yeast extract $(0.5 \%)$, was prepared in $250 \mathrm{ml}$ conical flask. The media was mixed to dissolve completely and then sterilized by autoclaving at 15 psi pressure, $121^{\circ} \mathrm{C}$ for 15 minutes. The media was allowed to cool before inoculating with the Bacillus subtilis followed by incubation at $30^{\circ} \mathrm{C}$ for 24 hours.

\subsection{Screening for PHB Producing Bacillus subtilis:}

The detection of PHB was done by lipophilic Sudan Black B stain as described by Singh and Parmar (2011). The Sudan Black B stain was prepared by dissolving $0.3 \mathrm{~g}$ in $100 \mathrm{ml}$ of $60 \%$ ethanol. Smears of B. subtilis were prepared on a glass slide and heat fixed. The samples were stained for 10 minutes with approximately $8 \mathrm{ml}$ Sudan black solution, rinsed with water and counter-stained with $0.5 \%$ safranin for 5 seconds. Stained samples were observed under oil immersion at $100 \times$ magnification with direct bright field illumination using an Olympus CX31 Microscope with luminesce infinity 2 CD Camera. Colony stained with Sudan Black B was selected as positive for PHB production.

\subsection{Production Media for Polyhydroxybutyrate (PHB):}

The production media used for the production of PHB contained the carbon source $(1 \%)$, yeast extract $(0.5 \%)$, sodium chloride $(0.1 \%)$, magnesium sulphate $(0.02 \%)$, peptone, and dipotassium hydrogen phosphate at $0.05 \%$ each. The media was mixed to dissolve completely followed by autoclaving at $15 \mathrm{psi}$ pressure, $121^{\circ} \mathrm{C}$ for 15 minutes. Inoculum $(2 \% \mathrm{v} / \mathrm{v})$ was then added to $100 \mathrm{ml}$ of production media prior to incubation at $30^{\circ} \mathrm{C}$ for 48 hour on a shaker at $150 \mathrm{rpm}$.

\subsection{Bioplastic (PHB) Extraction:}

After 48 hours of incubation, fermented broth was collected and centrifuged at $8000 \times \mathrm{g}$ for 10 minutes and the resulting pellets were washed with distilled water. Cell pellets were then air-dried and measured. Chloroform (98\%) and 6\% sodium hypochlorite were then added to cell pellets in a ratio of $1: 1$ (i.e. $12.5 \mu 1$ of $98 \%$ chloroform to $12.5 \mu 1$ of $6 \%$ sodium hypochlorite per mg of cell pellets to break the bacterial cell wall). This mixture was kept at $30^{\circ} \mathrm{C}$ overnight and centrifuged at $15000 \times \mathrm{g}$ for 10 minutes, which resulted in formation of three phases. The chloroform phase at the bottom containing PHB was carefully removed and PHB was recovered by precipitation with methanol and water in a ratio of 7:3 (Singh et al., 2009) and centrifugation at $15000 \times \mathrm{g}$ for 10 minutes.

\subsection{Bioplastic (PHB) Quantification:}

Quantitative assay for PHB was done using UV Spectrophotometry as described by Law and Slepecky (1961). Polyhydroxybutyrate crystals undergo dehydration on treatment with sulphuric acid and heat, to crotonic acid. The extracted PHB was converted to crotonic acid by adding $98 \%$ sulphuric acid and heating at $60^{\circ} \mathrm{C}$ for 1 hour. The crotonic acid showed maximum absorbance at $235 \mathrm{~nm}$ in a UV spectrophotometer against a sulphuric acid as a blank. The presence of peak around $230 \mathrm{~nm}$ $240 \mathrm{~nm}$ confirmed the presence of polyhydroxybutyrate.

\subsection{Determination of Bioplastic (PHB) Yield:}

Yield of PHB bioplastics was expressed in percentage (\%) based on the amount of PHB $(\mathrm{g} / \mathrm{L})$ formed and dry cell weight $(\mathrm{g} / \mathrm{L})$.

\subsection{Statistical Analysis:}

Values are presented as mean \pm standard deviation. Student's $t$ test was used to compare the means at $95 \%$ confidence level.

\section{RESULTS}

\subsection{Detection of Bacillus subtilis PHB producing strains:}

In the present study, Bacillus subtilis was cultured on nitrogen limiting media in order to determine its potential for PHB production. The visual screening using Sudan B Black stain serves as the first positive test for identifying the PHB potential strains. A potential strain was selected based on the appearance of dark blue or black stains when viewed under the microscope as indicated in Figure 1.

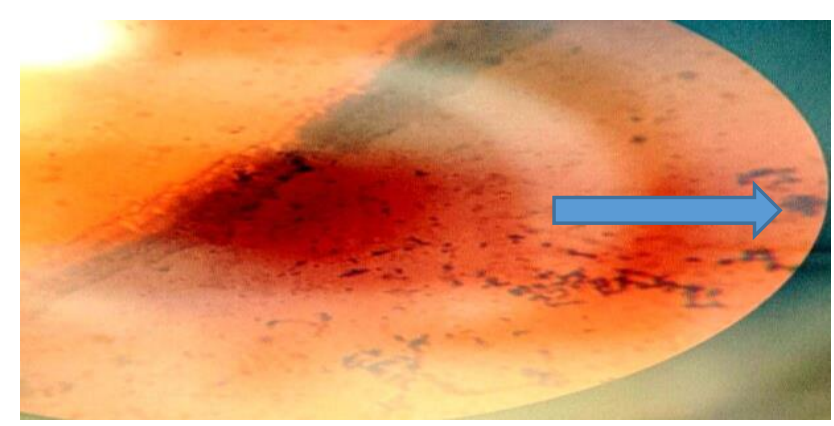

Figure 1. Photo micrograph of Bacillus subtilis Bioplastic (PHB) Producing Strains

\section{$3.2 \mathrm{pH}$ values of Pretreated Agricultural residues:}

The $\mathrm{pH}$ values of the four pretreated agricultural residues were presented in Table 1. Pretreated rice husk gave a $\mathrm{pH}$ value of 4.48 for acid, 7.07 for alkali and 6.05 for hydrogen peroxide pretreatments. Molasses had $\mathrm{pH}$ values of $6.05,7.10$ and 8.10 for acid, alkali and hydrogen peroxide pretreatments. In case of sugarcane bagasse, $\mathrm{pH}$ value of 5.30 was obtained for acid, 6.01 for alkali and 7.13 for hydrogen peroxide pretreatments. Similarly, highly acidic $\mathrm{pH}$ of 4.12 and 2.52 were found for acid and alkali pretreated corn cobs; while a $\mathrm{pH}$ of 9.06 was obtained for hydrogen peroxide pretreated corn cob.

Table 1. pH Values of Agricultural Residues after Acid, Alkali and Oxidative Pretreatments

\begin{tabular}{|c|c|c|c|}
\hline \multirow{2}{*}{ Residues } & \multicolumn{3}{|c|}{ Treatment } \\
\cline { 2 - 4 } & Acid & Alkali & $\begin{array}{c}\text { Hydrogen } \\
\text { peroxide }\end{array}$ \\
\hline Rice husk & 4.48 & 7.07 & 6.05 \\
Molasses & 6.50 & 7.10 & 8.10 \\
Sugarcane baggase & 5.30 & 6.01 & 7.13 \\
Corn cob & 4.12 & 2.52 & 9.06 \\
\hline
\end{tabular}




\subsection{Effect of Pretreatment on Dry Cell Weight (g/L) of Bacillus subtilis:}

From the results presented in Table 2, dry cell weight of alkali pretreated rice husk was found to be $3.31 \pm 0.01 \mathrm{~g} / \mathrm{L}$. This value was significantly $(\mathrm{p}<0.05)$ higher than that of acid $(3.01 \pm 0.02 \mathrm{~g} / \mathrm{L})$ and hydrogen peroxide $(3.19 \pm 0.01 \mathrm{~g} / \mathrm{L})$ pretreatments. For molasses, there was statistical significant $(\mathrm{p}<0.05)$ difference in cell dry weight values obtained for acid $(3.31 \pm 0.02 \mathrm{~g} / \mathrm{L})$, alkali $(3.01 \pm 0.02 \mathrm{~g} / \mathrm{L})$ and hydrogen peroxide $(3.18 \pm 0.01 \mathrm{~g} / \mathrm{L})$. In the case of sugarcane bagasse, there was significant $(\mathrm{p}<0.05)$ difference between alkali $(2.00 \pm 0.10 \mathrm{~g} / \mathrm{L})$ and acid $(1.63 \pm 0.12 \mathrm{~g} / \mathrm{L})$ pretreatments. However, there was no significant $(p>0.05)$ difference between hydrogen peroxide and the acid pretreated bagasse. Also, alkali pretreated corn cob showed cell dry weight value of $1.20 \pm 0.10 \mathrm{~g} / \mathrm{L}$, which was significantly $(\mathrm{p}<0.05)$ higher than what was obtained for the acid $(0.97 \pm 0.06 \mathrm{~g} / \mathrm{L})$ and hydrogen peroxide $(1.00 \pm 0.10 \mathrm{~g} / \mathrm{L})$ pretreatments.

Table 2. Bacterial Biomass formation in different Pretreated Agricultural Residues

\begin{tabular}{|c|c|c|c|}
\hline \multirow[t]{2}{*}{ Residues } & \multicolumn{3}{|c|}{ Cell Dry Weight (g/L) } \\
\hline & Acid & Alkali & $\begin{array}{c}\text { Hydrogen } \\
\text { peroxide }\end{array}$ \\
\hline Rice husk & $3.01 \pm 0.02^{\mathrm{a}}$ & $3.31 \pm 0.01^{\mathrm{b}}$ & $3.19 \pm 0.01^{\mathrm{c}}$ \\
\hline Molasses & $3.31 \pm 0.02^{\mathrm{c}}$ & $3.01 \pm 0.02^{\mathrm{a}}$ & $3.18 \pm 0.01^{\mathrm{c}}$ \\
\hline $\begin{array}{c}\text { Sugarcane } \\
\text { baggase }\end{array}$ & $1.63 \pm 0.12^{\mathrm{a}}$ & $2.00 \pm 0.10^{\mathrm{b}}$ & $1.77 \pm 0.15^{\mathrm{a}}$ \\
\hline Corn cob & $0.97 \pm 0.06^{\mathrm{a}}$ & $1.20 \pm 0.10^{\mathrm{b}}$ & $1.00 \pm 0.10^{\mathrm{b}}$ \\
\hline
\end{tabular}

\subsection{Polyhydroxybutyrate Production (g/L) and its Yield} (\%) from Different Pretreated Agricultural Residues:

Following the extraction of the produced PHB by B. subtilis, alkali pretreated rice husk showed a significantly $(\mathrm{p}<0.05)$ higher concentration of PHB of $1.82 \pm 0.01 \mathrm{~g} / \mathrm{L}$ than acid $(1.52 \pm 0.02 \mathrm{~g} / \mathrm{L})$ and hydrogen peroxide $(1.71 \pm 0.01 \mathrm{~g} / \mathrm{L})$ pretreated husks (Table 3 ).

Table 3. Polydroxybutyrate (PHB) Production $(\mathrm{g} / \mathrm{L})$ from Different Pretreated Agricultural residues

\begin{tabular}{|c|c|c|c|}
\hline \multirow{2}{*}{ Residues } & \multicolumn{3}{|c|}{ Cell Dry Weight $(\mathrm{g} / \mathrm{L})$} \\
\cline { 2 - 4 } & Acid & Alkali & $\begin{array}{c}\text { Hydrogen } \\
\text { peroxide }\end{array}$ \\
\hline Rice husk & $1.52 \pm 0.02^{\mathrm{b}}$ & $1.82 \pm 0.01^{\mathrm{c}}$ & $1.70 \pm 0.01^{\mathrm{b}}$ \\
Molasses & $1.82 \pm 0.01^{\mathrm{c}}$ & $1.52 \pm 0.02^{\mathrm{a}}$ & $1.69 \pm 0.01^{\mathrm{b}}$ \\
Sugarcane & $0.87 \pm 0.06^{\mathrm{a}}$ & $1.10 \pm 0.10^{\mathrm{b}}$ & $0.96 \pm 0.07^{\mathrm{a}} \mathrm{b}$ \\
baggase & & & \\
Corn cob & $0.50 \pm 0.00^{\mathrm{a}}$ & $0.77 \pm 0.06^{\mathrm{b}}$ & $0.60 \pm 0.10^{\mathrm{a}}$ \\
\hline
\end{tabular}

Values are means \pm standard deviation of three determinations. Values with different superscripts ( $\mathrm{a}, \mathrm{b}$ or $\mathrm{c}$ ) across the columns differ significantly at $p<0.05$. For molasses, acid pretreatment resulted in PHB production of $1.82 \pm 0.01 \mathrm{~g} / \mathrm{L}$, which was significantly $(\mathrm{p}<0.05)$ higher than those obtained for alkali $(1.52 \pm 0.02 \mathrm{~g} / \mathrm{L})$ and hydrogen peroxide $(1.69 \pm 0.01 \mathrm{~g} / \mathrm{L})$ pretreatments. Similarly, alkali pretreated sugarcane bagasse had a value of $0.77 \pm 0.06 \mathrm{~g} / \mathrm{L}$, which was significantly $(\mathrm{p}<0.05)$ higher value than the PHB concentrations found in other pretreatments. However, there was no significant $(p>0.05)$ difference in PHB concentration between the hydrogen peroxide pretreated bagasse $(0.96 \pm 0.07 \mathrm{~g} / \mathrm{L})$ and that of acid pretreatment $(0.87 \pm 0.06$ $\mathrm{g} / \mathrm{L}$ ). In case of corn cob, alkali pretreatment resulted in significantly $(\mathrm{p}<0.05)$ higher concentration of PHB $(0.77 \pm 0.06 \mathrm{~g} / \mathrm{L})$, followed by hydrogen peroxide $(0.60 \pm 0.10$ $\mathrm{g} / \mathrm{L})$ and the least was acid pretreatment $(0.50 \pm 0.00 \mathrm{~g} / \mathrm{L})$ as indicated in the table.

Thus, Table 4 shows the yield of PHB for different pretreated agricultural residues where alkali and hydrogen peroxide pretreated rice husks gave values of $53.33 \pm 2.23 \%$ and $53.29 \pm 0.15 \%$, respectively; with no significant $(\mathrm{p}>0.05$ ) difference between them. However, lower yield of PHB was obtained for acid pretreatment $(50.33 \pm 0.76 \%)$. In case of molasses, acid pretreated molasses had a yield of $54.94 \pm 0.47 \%$ which was significantly $(\mathrm{p}<0.05)$ higher than that obtained for hydrogen peroxide $(53.09 \pm 0.17 \%)$ and alkali pretreatments $(50.55 \pm 0.25 \%)$ as shown in Table 4 . For the PHB yield of pretreated sugarcane baggase, there was generally no significant ( $\mathrm{p}>0.05)$ difference between the acid $(53.33 \pm 6.68 \%)$, alkali $(55.00 \pm 4.33 \%)$ and hydrogen peroxide $(54.50 \pm 7.12 \%)$ pretreatments. Also, alkali pretreated corn cobs resulted in PHB yield of $63.94 \pm 2.59 \%$, and this value was significantly $(p<0.05)$ higher than what was obtained for the acid pretreated corn cobs $(51.85 \pm 3.21 \%)$. On the other hand, no significant $(\mathrm{p}>0.05)$ difference was observed between the PHB yield $(60.11 \pm 8.89 \%)$ of hydrogen peroxide pretreated corn cobs and the other pretreatment methods

Table 4. Bioplastic (PHB) Yield from Different Pretreated

\begin{tabular}{|c|c|c|c|}
\hline \multirow{2}{*}{ Residues } & \multicolumn{3}{|c|}{ Agricultural residues } \\
\cline { 2 - 4 } & Acid & Alkali & $\begin{array}{c}\text { Hydrogen } \\
\text { peroxide }\end{array}$ \\
\hline Rice husk & $50.33 \pm 0.76^{\mathrm{a}}$ & $53.69 \pm 2.23^{\mathrm{b}}$ & $53.29 \pm 0.15^{\mathrm{b}}$ \\
Molasses & $54.94 \pm 0.47^{\mathrm{c}}$ & $50.55 \pm 0.25^{\mathrm{a}}$ & $53.09 \pm 0.17^{\mathrm{b}}$ \\
Sugarcane & $53.33 \pm 6.68^{\mathrm{a}}$ & $55.00 \pm 4.33^{\mathrm{a}}$ & $54.50 \pm 7.13^{\mathrm{a}}$ \\
baggase & & & \\
Corn cob & $51.85 \pm 3.21^{\mathrm{a}}$ & $63.94 \pm 2.59^{\mathrm{b}}$ & $60.11 \pm 8.89^{\mathrm{a}, \mathrm{b}}$ \\
\hline
\end{tabular}

Values are means \pm standard deviation of three determinations. Values with different superscripts (a,b or c) across the columns differ significantly at $\mathrm{p}<0.05$.

\section{DISCUSSION}

Going by the results presenting the biomass production, the polyhydroxybutyrate (PHB) production and and its yield, it is evident that Bacillus subtilis has the potential for bioplastic (PHB) production when different agro-residues are used as carbon source.

The significantly higher $(\mathrm{p}<0.05)$ value of dry cell weight obtained for the alkali pretreated rice husk (Table 2) could be linked to the neutral $\mathrm{pH}$ of the residue (Table 1) which favored the growth and metabolism of the selected strain, B. subtilis. Also, PHB obtained from alkali pretreated rice husk was within the range of $50-90 \%$ of cell dry weight produced by commercial PHB producing bacteria such as Cupriavidus eutropha and recombinant E. coli (Steinbüchel, 2001). Other alkali pretreated agricultural residues had considerable yields of cell dry weight which could be ranked as molasses, sugarcane bagasse and then corn cobs.

In addition to low yield for cell dry weight in all acid pretreated residues, several draw backs have been associated with acid treatment including formation of degradation products of pentoses, hexoses and other compounds, such as furfural, hydroxyl-methyl furfural, acetic acid, formic acid and levulinic acid, which affects microbial bioconversion processes (Balat et al. 2008). The low $\mathrm{pH}$ of the acid pretreated agricultural residues might have affected the growth of Bacillus subtilis, whose growth optimum $\mathrm{pH}$ is towards neutrality. However, in the case of molasses, acid pretreatment resulted in significantly higher cell dry weight, when compared with other pretreatments. Gazaerly (1983) found that the acid pretreatment of molasses reduced the concentration of both $\mathrm{Zn}$ and $\mathrm{Cu}$ ions by about $25 \%$, making the available carbon more accessible for utilization by 
microorganisms; this could serve as an explanation for the observed effect. Similarly, Helal (1986) found that when molasses was treated with $\mathrm{H}_{2} \mathrm{SO}_{4}$ and added into the fermentation medium as sole carbon source, it increased the cell dry weight yield with minimal reduction in nitrogen content.

In case of oxidative pretreatment using $\mathrm{H}_{2} \mathrm{O}_{2}$, Hon and Shiraishi (2001) have noted that several reactions may occur during oxidative pretreatment which include displacement of side chains, electrophilic substitution and cleavage of alkyl aryl ether linkages or oxidative cleavage of aromatic nuclei. These reactions help in removing the lignin and thereby increasing accessibility of cellulose for utilization by microbial species (Singh and Bishnoi, 2013). This may have contributed to the high cell dry weight of B. subtilis observed in this study. In addition, these results are indicative that organic substatnces/by - product inhibitors eg furans, ferulic acids, phenolic acids etc usually produced as a result of lignocellulosic degradation by acids and alkali did not stop the microorganism from using the pretreated agro-residue from in the production of the PHB. This a welcome development considering the fact that recalcitrant by-product inhibitors tend to affect microorganisms efficiency in the production of value added products from acid, alikali and oxidative pretreated agro-residues (Johnson and Martin, 2016).

Based on the findings in this study (Tables 2, 3 and 4), there is direct relationship between the cell dry weight of B. subtilis and the concentration of PHB produced. This observation implies that factors that favor increase in B. subtilis growth also favor the PHB production. However, when the overall yield was determined the aforementioned relationship may be influenced by other environmental factors.

\section{REFERENCES}

Balat M., Balat H. and Oz C. (2008). Progress in bioethanol processing. Prog Energ Combust 34, 551573.

Barham P.J. (1990). Physical properties of poly(hydroxybutyrate) and poly(hydroxybutyrate-co hydroxyvalerate). Novel Biodegradable Microbial Polymers, Kluwer, Dordrecht. PP 81-96.

Braunegg G., Lefebvre G. and Genser K.F. (1998). Polyhydroxyalkanoates, Biopolyesters from Renewable Resources: Physiological and Engineering Aspects. $J$ Biotechnol. 65, 127161.

Byrom D. (1987). Polymer synthesis by microorganisms: technology and economics, TIBTECH 5, 156-167.

Castro-Sowinski S, Burdman S, Matan O, Okon Y (2010) Natural functions of bacterial polyhydroxyalkanoates (Chen GQ Editor.) Plastics from bacteria. Springer, Berlin, Heidelberg. PP, 39-61.

Choi J. and Lee S Y (1997) Process analysis and economic evaluation for Poly (3-hydroxybutyrate) production by fermentation. Bioprocess Engineering, 17(6), 335-342

Dashtban M., Schraft H. and Qin W. (2009). Fungal bioconversion of lignocellulosic residues; opportunities and perspectives. Int Biol Sci, 5(6), 578-595

Gazaerly M.A. (1983). The utilization of beet molasses for single cell protein production [M Sc Thesis]. Botany Department, Faculty of Science, Alexandria University, Egypt.

Hassan, M. A., Shirai, Y., Kusubayashi, N., Abdulkarim, M. I., Nakanishi, K. and Hashimoto, K. (1996). Effect of Organic Acid Profiles during Anaerobic Treatment of Palm Oil Mill Effluent on the Production of Polyhydroxyalkanoates by Rhodobacter sphaeroides. Journal of Fermentation and Bioengineering 82(2), 151 $-156$.

Helal G.A. (1986). Protein and fats from halophilic fungi [Ph.D Thesis]. Department of Botany, Faculty of Science, Zagazig University, Egypt.

Hon DNS, Shiraishi N (2001) Wood and cellulosic chemistry, Second Edition. Dekker, New YorkJiun-Yee C., SugamaSalim Y., Nyok-Sean L., Siew-Chen L., Raed M. M. A., and Kumar S. (2010) Bacterially Produced Polyhydroxyalkanoate (PHA): Converting Renewable Resources into Bioplastics (A. Mendez-Vilas: Editor). Current Research, Technology and Education Topics in Applied Microbiology and Microbial Biotechnology. PP, 1395-1403.

Johnson L. J., and Martin C. (2016). Pretreatment of Lignocellulose: Formation of Inhibitory by-products and Strategies of Minimizing Their effects. Bioresource Technology, 199, 103112.

Law J.H., and Slepecky R.A. (1961). Assay of Poly_ hydroxyl butyric acid. J Bacteriol. 82: 33-36.

Lopez J.A., Naranjo J.M., Higuita J.C., Cubitto M.A., Cardona C.A., Villar M.A. (2012). Biosynthesis of PHB from a New Isolated Bacillus megaterium strain : Outlook on Future Development with Endospore Forming Bacteria. Biotechnology and Bioprocess Engineering. 258, 250-258.

Luengo M. J., Garcia B., Sandoval A., Naharro G.,and Olivera E. R.(2003) Bioplastics From Microrganisms. Current Opinion in Microbiology, 6:251-260.

Rodriguea-Contreras A., Koller M, Miranda-de Sousa Dias M, CalafellMonfort M, Braunegg G and Marqués-Calvo MS.(2013) High production of poly(3-hydroxybutyrate) from a wild Bacillus megaterium Bolivian Strain. Journal of Applied Microbiology, 114(5),1378-1387.

Saharan B. and Sharma D., (2012). Bioplastics for sustainable development: A Review. International Journal of Microbial Resource Technology, 1,11-23.

Sanchez C., (2009). Lignocellulosic residues: biodegradation and bioconversion by fungi. Biotechnol Adv, 27(2), 185-194

Singh P., Ashwini P., Avinash A.K., Badri R., and Kajal D., (2009). Mutagenesis of Bacillus thuringiensis IA 12077 for increasing pol (- $\beta$-) hydroxybutyrate (PHB) production, Turk. J. Biol., $33,225-230$

Singh A, and Bishnoi N.R., (2013). Comparative study of various pretreatment techniques for ethanol production from water hyacinth. Ind Crops Prod, 44, 283-289.

Singh P. and Parmar, N., (2011). Isolation and characterization of two novel polyhydroxybutyrate (PHB) producing bacteria. African J. Biotechnology, 10, 4902-919.

Steinbüchel, A. (2001). A. Perspectives for biotechnological production and utilization of biopolymers: metabolic engineering of polyhydroxyalkanoate biosynthesis pathways as successful example. Macro Biosci, 11:1-24.

Sudesh K, and Iwata $T$ (2008) Sustainability of biobased and biodegradable plastics. Clean - Soil, Air, Water 36: 433-442.

Tripathi, A.K., P.B. Tiwari, Mahima and D. Singh (2009) Assessment of air pollution tolerance index of some trees in Moradabad city. Indian J. Environ. Biol, 30, 545-556.

Wang, H.H., Li, X.T., and Chen, G. Q. (2009). Production and characterization of homopolymer polyhydroxyheptanoate by a fadBA knockout mutant Pseudomonas putida KTOY06 derived from P. putida KT2442. Process Biochemistry 44(1), 106-111.

Williams, S. F. and Martin, D. P. (2002) Applications of PHAs in Medicine and Pharmacy. Wiley -VCH, Weinheim PP, 91-121. 